Meta

Journal des traducteurs

Translators' Journal

\title{
Guillaume Oyono-Mbia: A Bilingual Playwright
}

\section{Unionmwan Edebiri}

Volume 38, numéro 3, septembre 1993

URI : https://id.erudit.org/iderudit/002693ar

DOI : https://doi.org/10.7202/002693ar

Aller au sommaire du numéro

Éditeur(s)

Les Presses de l'Université de Montréal

ISSN

0026-0452 (imprimé)

1492-1421 (numérique)

Découvrir la revue

Citer cette note

Edebiri, U. (1993). Guillaume Oyono-Mbia: A Bilingual Playwright. Meta, 38(3), 576-582. https://doi.org/10.7202/002693ar

\section{Résumé de l'article}

Dans la traduction de ses œuvres dramatiques, Guillaume Oyono-Mbia prend des libertés que peut seul se permettre un auteur-traducteur. Il est d'ailleurs erroné de parler de traduction dans ce cas, car le même auteur étant à la source des deux textes, ceux-ci constituent des originaux. Le processus mis en œuvre ici relève moins de la traduction proprement dite que de la réécriture. d'utilisation que vous pouvez consulter en ligne.

https://apropos.erudit.org/fr/usagers/politique-dutilisation/ 


\section{LES DROGMANS DE MALAISIE}

La traduction du français au malais et vice-versa n'a pas atteint sa vitesse de croisière. Certes elle ne date pas d'hier, puisqu'un grand nombre d'orientalistes français nous ont précédés dans la carrière et ont effectue, au siècle dernier, plusieurs traductions pour faire connaître, au public français, la richesse de la littérature classique malaise. Comme la liste de ces traducteurs est assez longue, il suffira d'en évoquer quelques représentants, tels Édoudard Dulaurier, le père des études malaises en France, Aristide Marre, Marcel Devic, Alfred Tugault, etc.

Un nouvel élan est apparu dans les années 1980 dans les deux sens, français-malais et malais-français. C'est en effet à partir de 1982 que plusieurs romans malais ont pu être lus par nos compatriotes par le biais des traductions. Ainsi S. Othman Kelantan, Shahnon Ahmad, Anwar Ridhwan et aussi un certain nombre d'auteurs de nouvelles ont pu être lus, et appréciés, en français. Parallèlement donc, plusieurs ceuvres françaises ont été mises à la portée des lecteurs de Malaisie. Des auteurs variés ont pu de cette façon avoir des lecteurs malaisiens. Maupassant, Roland Barthes, Jean-Jacques Rousseau, Georges Mounin ont reçu un auditoire supplémentaire par le truchement de la traduction en malais.

Néanmoins tout n'est pas parfait - et loin de là - dans cette mise à la portée du pays cible d'une littérature étrangère. Les traductions du siècle dernier étaient en particulier bien souvent partielles, sinon partiales. Il faut leur reconnaittre en tous cas une qualité, celle d'avoir été accomplies et, du reste, souvent d'avoir précédé certaines traductions (certes plus complètes, mais plus tardives en langue anglaise ou hollandaise). Celles de ce siècle semblent assez disparates, non que la qualité du travail soit mis en cause, mais - dans les milieux bien informés - on constate et on semble déplorer plutôt une trop grande variété dans les choix proposés aux lecteurs cibles. Alors on a songé à la constitution de programmes de traductions et plusieurs listes ont ainsi été proposées à la grande maison d'édition nationale de Malaisie, le Dewan Bahasa dan Pustaka. Tout d'abord le Bureau d'action linguistique, à l'époque où celui-ci était dirigé par Pierre Mattot a présenté une première liste à cet établissement, puis René Daillie, du temps où ce dernier était en mission au Dewan Bahasa dan
Pustaka, en a fourni une autre, Pierre Labrousse de I'INALCO de Paris, auquel on s'était adressé, en a compilé une autre, enfin votre serviteur, qui lui aussi s'est intéressé à cette question, a fait de même et a donc soumis au DBP, une autre liste. Le résultat de tout ceci a été que ces listes étaient différentes et en fait fort différentes. On doit tout de suite comprendre que le contraire eût été surprenant. Il est donc tout à fait naturel que ces listes soient différentes les unes des autres. Une première question se pose alors. Doiton proposer une liste rigide et s'en tenir à cette liste, ou tenter de faire autre chose? Nous voudrions ici rappeler un propos de l'éditeur Hubert Nyssen, qui a eu - entre autres - la particularité de s'installer en province, d'y rester et de prouver ainsi qu'on pouvait réaliser quelque chose en dehors de la capitale française : à la question de savoir ce qu'il publiait, il a répondu (bien sûr c'était au début de l'aventure d'Actes Sud, sa maison d'édition d'Arles) qu'il cédait souvent à des coups de cœur. Dans le domaine de la traduction, doit-on proposer une liste étroite et fermée et ne s'en tenir qu'à cette liste? Nous ne le pensons pas, et les coups de cour doivent également intervenir dans cette activité. Ainsi au lieu de ne proposer que quelques choix aux traducteurs (ou aux traducteurs potentiels) il est préférable de leur laisser carte blanche. À eux donc de déterminer quel texte ils devraient proposer à leurs lecteurs. C'est le traducteur qui doit être le chercheur, le prospecteur, le découvreur du texte étranger susceptible d'intéresser les lecteurs du pays cible. Tout le monde sait très bien qu'on traduit mieux ce qu'on apprécie et ce qu'on aime, qu'un texte imposé et qui ne nous plaît guère.

Au-delà du choix du texte, qui doit donc être laissé au traducteur, d'autres embûches apparaissent sur le chemin étroit de la traduction. Ainsi le traducteur a choisi une ouvre, a passé de longs moments à lire et à traduire et alors il se met en quête (s'il ne l'a pas encore fait) d'un éditeur. La chose n'est pas aisée et notre traducteur, qui s'est beaucoup dépensé et fai cuvre de pionnier, ne trouve pas facilement un éditeur qui accepte de publier sa traduction. Le traducteur est enfermé dans un cercle vicieux. Il tente de faire connaître un exemple d'une littérature peu connue en France - en fait, que connaissons-nous en France des littératures d'Asie? Bien sûr, nous disposons d'une série de traduction d'œuvres chinoises: nous avons aussi, dans une moindre mesure, de 


\section{GUILLAUME OYONO-MBIA: \\ A BILINGUAL PLAYWRIGHT}

Résumé

Dans la traduction de ses cuvres dramatiques, Guillaume Oyono-Mbia prend des libertés que peut seul se permettre un auteur-traducteur.II est d'ailleurs erroné de parler de traduction dans ce cas, car le même auteur étant à la source des deux textes, ceux-ci constituent des originaux. Le processus mis en couvre ici relève moins de la traduction proprement dite que de la réécriture.

Uriel Weinreich defines bilingualism as "the practice of alternatively using two languages" and qualifies the person who takes to it as bilingual. ${ }^{1}$ The bilingual frequently engages in translation which, 
according to Eugene A. Nida, "consists in producing in the receptor language (also called the target language) the closest natural equivalent of the message of the source language, first in the meaning and secondly in style." 2 Nida's definition is appropriate for other forms of translation but it is somehow inadequate for the translation of drama texts, owing to the very nature of drama itself.

Since a play is culture bound and meant essentially for performance, its translator must aspire to reproduce in the target language both the linguistic and especially the cultural elements which constitute its stageworthyness. ${ }^{3}$ It is for this reason that the literary translator, in the words of Andre Lefevbre, "has to be a citizen of two worlds." 4 But Lefevere's remark ought to be modified in the case of Guillaume OyonoMbia whose plays and translations are rooted in the same Cameroonian culture.

In this regard, he stands apart from a writer like Samuel Beckett, with whom he can be readily compared mainly on the ground that both of them use English and French in their creative writing and translating endeavours. In fact, it can be correctly argued that Oyono-Mbia whose works within a mono-cultural background is even more fortunate than Beckett, since unlike the Irish Playwright who has to render his works from English into French and vice versa, he does not have to undertake the tricky and challenging task of translating "the socio-cultural framework of one world into another," to borrow Lefevere's expression.

From the linguistic point of view, it is clear that Oyono-Mbia expresses himself with almost equal facility in both French and English. Like Beckett, he writes in both of them and translates his works to and from the two languages. In this regard, it is of particular interest to the student of bilingualism to note that Oyono-Mbia's drama falls into two broad categories. The first category includes plays written originally in French, like Trois prétendants... un mari (1960) and Notre fille ne se mariera pas (1971). (He subsequently translated the former into English as Three Suitors... One Husband in 1967.)

The second group consists of Until Further Notice (1967) and His Excellency's Special Train (1969), which he composed in English and later translated into French, respectively as Jusqu'à nouvel avis (1967) and Le train spécial de son Excellence (1973). Unlike his other plays whose translations were published separately, His Excellency's Special Train and Le train spécial de son Excellence were issued in a bilingual edition. Does this indicate a new trend with Oyono-Mbia? Only the future years will tell if he will henceforth publish new plays only in bilingual editions.

Oyono-Mbia's bilingualism is essentially the result of his educational training. At the time he started going to school, French was the language of instruction and the only official language in the French Cameroon where he was born. ${ }^{5} \mathrm{He}$ began the study of English in the secondary school, and went on to take a combined degree in French and English at the University of Yaounde. He later studied for a doctorate degree in European studies at the University of Keele, Staffordshire in England. Then, after a stint as lecturer at the University of Yaounde, Oyono-Mbia now works in the Ministry of Information and Culture, a position which affords him the opportunity to maintain and cultivate his bilingualism. However, it is important to note that, as a predominantly Frenchspeaking town, Yaounde offers Oyono-Mbia far more opportunities of speaking French than English in his professional as well as social life.

\section{GOOD TRANSLATION}

Oyono-Mbia is justifiably more concerned with the accurate translation of the meaning of a speech from one language into another (from English into French, and vice versa) than with paying scrupulous attention to the form and length of the speech. The following examples can illustrate this method.

Bikokoe Mendegue: $C^{\prime}$ est pour cela! Les grands personnages doivent toujours avoir les meilleures choses de la terre ! (Le train, p. 18)

In the English version, he does not bother to translate de la terre which would not add to the meaning of the passage:

Bikokoe Mendegue: Exactly! Great men must always have the best! (His Excellency's, p. 18)

In another passage we have:

Missa Majunga: (...) On ne connaissait pas encore cette vogue de vin de palme et de boissons distillées localement. (Le train, p. 24)

Missa Majunga: (...) Nobody ever touched palm wine, or any of the locally distilled spirits, which have become so popular today. (His Excellency's, p. 24)

In the English version, he translates the idea which the character wishes to convey and therefore shuns a literal rendition of his speech. The English version is obviously longer than the French version, as he translates vogue, the key word in this passage by have become popular today. He prefers this expression to the abstractnous popularity or fashion.

As a good translator, Oyono-Mbia is able to make allowance for the cultural connotations of apparently ordinary expressions in order to bring out their realistic contextual meanings. For instance, in the following passage, rendre visite is not used in its ordinary sense to pay a visit or to visit, but in the sense of to woo a lady, to ask a lady's hand in marriage. In the context of this play, therefore, rendre visite à une femme implies a readiness on the part of the man or visitor to pay the customary bride-price as the examples of Ndi and Mbia clearly show. It follows that he must have enough money on him during such a visit. Thus, the author/translator is right in using go courting to translate rendre visite à une femme: 
Atangana: Un vrai fonctionnaire ne va pas rendre visite à une femme sans s'être au préalable muni d'une forte somme d'argent. (Trois prétendants, p. 17)

Atangana: No real civil servant would go courting without a large sum of money in his pocket. (Three Suitors, p. 12)

Also, as a good translator, Oyono-Mbia respects the language register of the passages he has to render in the one or the other of the languages. For instance, he translates the vulgar French in this passage into a correspondingly vulgar English:

Bikokoe Mendegue: (...) En tous cas il faut que moi,j'aille pisser. (Le train, p. 27)

Bikokoe Mendegue: Anyway, I must go and have a pee. (His Excellency's, p. 27)

\section{DIFFERENCES BETWEEN ORIGINAL AND TRANSLATED TEXTS}

The reader observes a number of differences between the French and English versions of OyonoMbia's plays. These differences are due to his additions to, deletions from or slight alterations of, the original texts when he translates them. Generally, the additions are often simple amplifications of the dialogues while the omissions hardly detract from the contents of the original. The author/translator's reasons for lengthening, shortening or slightly modifying the original texts are easily understandable in some cases while they are very difficult if not impossible to explain in others.

For instance, in the following translations the underlined words are additions to the original dialogues:

Abessolo: Your younger sister Matalina has just come back from overseas with her great man! They could easily pay back your husband! (Until, p. 96)

Abessolo: Sois tranquille, Ada! Aussi vrai que je suis Abessolo, fils d'Essindi, neveu de la noble tribu des Essamkom, tout va bientôt s'arranger!

Matalina ta soeur cadette, arrive cet après-midi avec son grand homme. Ils vont rembourser à ton mari l'argent qu'il nous avait versé ! (Jusqu'à, p. 24)

In this example, the genealogical facts which Abessolo gives about himself do not add to the meaning of his speech in English. It is therefore impossible to understand Oyono-Mbia's intention for providing them.

Similarly, his reason for adding to the English version of Mezoe's speech is impossible to explain here:

Mezoe: She promised! Besides, she wants to work in a big, modern hospital like the one in Yaounde, where she would only give orders to the less educated girls... (Until, p. 102)
Mezoe: Elle a promis de suivre mes conseils! D'ailleurs elle-même n'a aucune envie d'aller travailler en brousse, loin des cinémas et des magazins de produits de beauté. Elle préfère travailler dans un grand hôpital moderne comme celui de Yaoundé: c'est là qu'elle se contenterait de donner des ordres aux filles moins instruites qu'elle. (Iusqu'à, pp. 32-33)

The addition states her preference for work in the town where she can go to the cinema and buy the cosmetics she needs whereas the original statement stresses only her position in her place of work and the influence as well as the authority which goes with it. Thus, the addition contains an entirely new and different fact which has no clear logical connection with the meaning of the original.

But the author/translator's addition to Meka's speech in this example merely amplifies it by stating clearly why he used to give her some cocoa whenever she was about to return to school.

Meka: And I always said to her: "Go to the kitchen, my daughter. Ask your mother Makrita to give you one kilogramme of cocoa. You'ill sell it on your way to Metet, in Awae." (Until, p. 99)

Meka: Et moi, je lui disais, toujours: "Va à la cuisine, mon enfant! Demande à ta mère Makrita de te donner un kilo de cacao sec: tu le vendras au marché d'Awae, pour t'acheter des cahiers et

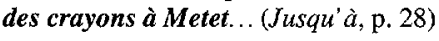

Also, in this excerpt where Nkatefoe and Abessolo discuss the latter's former wife, Oyono-Mbia's additions in his translation provide more information about her beauty than that which is contained in the original. In fact, apart from their logical connection with the original, the additions underline her beauty:

Nkatefoe: (with surprising sensuality) Hmm!... She was a woman!

Abessolo: A woman! And what a good land too! That's where women never speak when men are speaking, and you can cut your wife's head off if she dares to turn her back on you in bed during the night... No missionaries, no... (Until, p. 106)

Nkatefoe: (Avec une sensualité un peu surprenante) Hmm ! C'était une femme!... Sa poitrine n'était pas encore pleinement formée, mais..

Abessolo: Elle n'avait encore que des épines de fromage sur la poitrine, mais c'était une vraie femme!

Un temps, il continue sur une note encore plus nostalgique.

Et quel beau pays, ah Nkatefoe! C'est là que les femmes ne parlent jamais quand les hommes parlent. Tu peux très bien couper le cou à ta femme si jamais elle ose te tourner le dos au lit pendant la nuit... pas de missionnaires, pas de... (Jusqu'à, p. 38) 
The reader observes one addition in his translation of His Excellency's Special Train

The Stationmaster: Your special train should normally have been two hours late, Your Excellency. But..., (with a military salute) thanks to my relentless and tireless efforts, I beg to officially inform you that the delay has been reduced to 120 minutes exactly. (His Excellency's, p. 57)

Le chef de gare: Votre train spécial avait, officiellement, deux heures de retard, Excellence. Mais (...) (avec un salut militaire). Grâce aux efforts inlassablement dignes d'éloges que j'ai inlassablement déployés j'ai le respectueux honneur de vous annoncer officiellement que ce retard a été réduit à cent vingt minutes. (Le train, p. 59)

Oyono-Mbia's addition to the Stationmaster's speech is meant to emphasize how great his efforts have been to ensure that His Excellency is not kept waiting for the train for too long.

Similarly, Oyono-Mbia's translation of Trois prétendants... un mari contains only one addition:

Ondua: (méthodique) Il me faut, pour moi... euh... un grand lit en fer... un matelas en coton... euh... une armoire, des cou... (Trois prétendants, p. 42)

Here the author/translator adds "ten cases of red wine, twenty bottles of" presumably white wine or any other imported liquor to Ondua's demands.

It is not only through additions that Oyono-Mbia incorporates changes of varying degrees in his translations. Sometimes, he makes deliberate omissions when he translates from one language into the other as can be seen from the following examples:

Meka (impatiently): Patient? You want us to be patient! Don't you realize that man will soon be getting both his own and the salary of the daughter whose education we paid for? Why do you think he wants to take her to that hospital somewhere in the bush? He wants to stop us... (p. 102)

Meka (impatiemment): Patience? Tu nous dis de prendre patience? Tu ne vois pas que cet hommelà va bientôt toucher son propre salaire en même temps que le salaire de la fille dont nous avons nous-mêmes payé les frais d'instruction? (p. 32)

In the French translation, in addition to Meka's uncompleted sentence, Oyono-Mbia also deletes his rhetorical question which serves to reinforce the main point of his speech. In doing so, he thinks that such emphasis is not really necessary.

In Three suitors... one husband, he makes this rather long excision:

Kouma: Pas encore! En fait, il leur reste encore bien des bouteilles d'arki à vider! Et le chef de village m'a dit: "Mon fils, viens saluer Mbia, ton beau-frère ! C'est lui le grand fonctionnaire qui vient de payer deux cent mille francs de dot pour ta cousine Juliette. Dorénavant, si tu vois un de ces vauriens de collégiens tourner autour d'elle, dis-lui que Juliette est une femme mariée... Mon gendre Mbia nous a versé deux cent mille francs.." (p. 55)

Kouma: Not yet! They still have quite a few bottles to empty, as a matter of fact. And the headman said to me: "Come and greet Mbia, your brother-in-law!... He's the great civil servant from Sangmelima who's just paid two hundred thousand francs for your cousin Juliette!" (p. 40)

It is difficult to explain why Oyono-Mbia deletes from his translation this passage which throws light both on Abessolo's contempt for young students who cannot pay bride-prices on girls whom they want to marry, and on his joy that his family has found in Mbia a rich prospective son-in-law.

Discrepancies between the French and English versions of Oyono-Mbia's plays are not limited to dialogues alone; they are to be found also in the stage directions. However, as with the dialogues, they are due to additions to, deletions from or modifications of, the original texts. For example, just at the moment when Juliette asks her parents if they really expect her to refund the school fees they paid for her, in the course of the discussion during which they try to persuade her to marry the rich civil servant, Mbia, the author gives this stage direction in connection with the arrival of Mbia's car.

Ici, on entend le bruit caractéristique d'une grosse Mercedes Benz qui s'arrête sur la route, mais les acteurs sont trop scandalisés par la réplique de Juliette pour faire attention. (Trois prétendants, p. 25)

This stage direction which relates to how Mbia carries himself and speaks during his visit to his prospective parents-in-law is absent from the English version of the play. Moreover, the English translation omits the comparative clause and is not as precise as the French original:

Mbia: (Se lève majestueusement et parle avec autant de solennité qu'un sous-préfet le jour de l'indépendance.) (p. 31)

Mbia: (Stands up majestically and speaks solemnly.) (p. 22)

It may also be noted that...

Differences also exist between the stage directions in Until Further Notice and its French translation, Jusqu'a nouvel avis. For instance, early in the play, where Abessolo orders Mezoe to get some drinks for the elders of the village who have gathered to await the arrival of Matalina and her husband, the dramatist writes this stage direction:

(Mezoe goes to fetch a calabash of palm-wine at the far corner.) (p. 97) 
In the French text, this is given as:

(Mezoe se dirige vers les calebasses de vin de palme tandis que Meka allume sa pipe à l'aide d'allumettes empruntées à Abessolo. Nkatefoe regarde tout ceci d' un ail désapprobateur.) (p. 25)

Thus the French text is longer as it contains information about Abessolo and Nkatefoe which is not in the original English text. The English text also specifies the location of the palm-wine whereas the French does not.

Then, as Abessolo recalls with a feeling of nostalgia his former wife and her country (probably Equatorial Guinea or Fernando Po), the author observes in French:

Un temps: il continue sur une note encore plus nostalgique. (p. 38)

This stage direction is an addition to the French translation since it is absent from the original English text (p. 106).

Finally, the stage directions which bring the play to an end describe the light-hearted mood of Abessolo, the Driver and his Companion who have been feasting themselves on Abessolo's palm-wine which, in the words of the old man, is "the best palmwine in the whole Fong region."

These stage directions read as follows in English:

The three of them burst out laughing heartily. Their laughter is soon covered by Meka's enthusiastic message on the talking drum, and the curtain falls a few moments later. (p. 113)

In the French text, we have:

Tous les trois partent d'un énorme éclat de rire qui est bientôt couvert par le message de Meka au tam-tam, derrière la maison principale. Lorsque le rideau tombe quelques instants plus tard, nous avons une brève et dernière vision d'Abessolo versant à boire au chauffeur et à son compagnon. La mine réjouie de ces derniers montre clairement que le vin de palme d'Abessolo est sans conteste le meilleur dans tout le pays Fong. (p. 48)

Thus, the stage directions in the French version are longer, and contain additional facts about the three revellers than those given in the English version of the play.

It is evident from the examples we have given above that Oyono-Mbia incorporates changes of varying degrees when he translates his plays from French into English and vice versa. Although these changes are fairly numerous, they are nonetheless generally minor and do not, in the final analysis, amount to such profound modifications as to make the translated versions of his plays distinctly different from the originals. Even then a translator other than the author himself would expose himself to charges of infidelity to the original if he made similar or the same changes in his translations of the plays. ${ }^{6}$ But the charges of infidelity cannot be levelled against Oyono-Mbia since, as the source of the original and the translation, both texts of each play enjoy the same degree of authenticity. Thus, in translating his work, an author can take some liberties which a different translator cannot. It follows that, in translating his own work, an author invariably rewrites it and the process of rewriting is a dynamic one.

\section{COMIC EFFECT}

Any serious consideration of Oyono-Mbia's bilingualism must take into account his ability to transfer the comic quality of the original texts into his translations since all his plays are social comedies. Here again, he succeeds in remaining as comic in English as in French. The following speech of the Stationmaster who is striving to ingratiate himself with His Excellency at all cost is as amusing in French as in English:

Le chef de gare: Votre train spécial avait, officiellement, deux heures de retard, Excellence. Mais (...) (avec un salut militaire). Grâce aux efforts inlassablement dignes d'éloges que j'ai inlassablement déployés j'ai le respectueux honneur de vous annoncer officiellement que ce retard a été réduit à cent vingt minutes. (Le Train, p. 59)

The Stationmaster: Your special train should normally have been two hours late, Your Excellency. But..., (with a military salute) thanks to my own relentless and tireless efforts, I beg to officially inform you that the delay has been reduced to 120 minutes exactly. (His Excellency's, p. 57)

Oyono-Mbia gets across in the two languages the amusing element in the Stationmaster's speech; the first is the officialese or elaborate language which he uses in order to impress His Excellency favourably but which is not effective because it betrays its intention. The second is his smart attempt to claim credit for having influenced the reduction of the train's delay of two hours to one hundred and twenty minutes, that is, by expressing the same period of time in minutes instead of in hours!

Notice also the obscene humour in the following remark in which Bilomba insinuates that Folinika is still sexually virile in spite of her claim to old age:

Bilomba: (...) D'ailleurs, tout le monde sait que lorsque c'est ton tour, le pauvre Missa Majunga ne parvient plus à fermer l'oil de la nuit. (p. 22)

Bilomba: (...) Besides, we all know you're still managing to keep Missa Majunga very warm and very active in bed, eh? (p. 22)

In Until Further Notice the ignorance exhibited by Abessolo and his wife about the difference 
between a doctor and a midwife, provokes a mood of laughter:

Cecilia: (...) Matalina also went there to become a doctor, you know!

Mezoe (sitting down): A midwife.

Cecilia: What's the difference?

Abessolo: A doctor is a man; a midwife is his wife. (Until, p. 98)

(Oyono-Mbia's French translation of this dialogue is equally ridiculous:)

Cecilia: (...) Matalina est allée là-bas pour devenir docteur elle aussi, vous savez!

Mezoe: (...) Sage-femme, Na Cecilia.

Cecilia : N'est-ce pas la même chose?

Abessolo: Non évidemment : les docteurs sont des

hommes: les sages-femmes sont leurs femmes.

(Jusqu'à, p. 26)

It is obvious from the above examples that, as far as their comic quality is concerned, there is nothing to choose between the original and the translated versions of Oyono-Mbia's plays.

\section{MISTAKES}

Finally, it is pertinent to point out that OyonoMbia's works are not totally devoid of grammatical errors which can be explained in most cases by linguistic interferences. For instance, he translated nostalgique (Le train, p. 24) by "with a touch of nostalgy" (His Excellency's, p. 36). This is a case of false friendship for, needless to say, nostalgy does not exist in English. Nostalgique of course can be rendered in English by nostalgically or with nostalgia.

Also, Oyono-Mbia uses tautology in the following sentence:

Matalina... Tu ne marcheras plus jamais à pied... (Trois prétendants, p. 27)

But he translates it correctly in English:

Matalina... You'll no longer have to walk. (Three Suitors, p. 19)

Oyono-Mbia's translation of each of the following sentences is incorrect:

Bikokoe Mendegue: Atangana lui avait égorgé deux porcs bien gras. (Le train, p. 38)

Bikokoe Mendegue: Atangana killed him two fat pigs. (His Excellency's, p. 37)

A correct translation should read:

Atangana slaughtered two fat pigs for him

or better still:

Atangana slaughtered two fat pigs in his honour.
Oyono-Mbia uses justly to translate $j$ " avais raison in the following sentence where "with some justification or confidently is more appropriate.

Atangana: En l'envoyant au collège, $j$ 'avais bien raison de dire à tout le monde: «Un beau jour, cela me rapportera.» (Trois prétendants, p. 15)

Atangana: When I sent her to secondary school, I was but saying to everybody: "Some day I'll benefit from that!" (Three Suitors, p. 11)

Finally, Oyono-Mbia mixes up the correct French expression: être né sous une bonne étoile.

Matalina: Ma cousine est vraiment née avec une étoile sur le front! (Trois prétendants, p. 11)

He goes on to translate it word for word, thus mixing up the well-known English equivalent of the French expression:

Ma cousine est vraiment née sous ane bonne étoile!

My cousin was definitely born under a lucky star.

However insignificant the grammatical flaws cited above may appear, they cannot but be taken into consideration in a study which examines OyonoMbia's bilingualism, that is, his mastery of both French and English. Hence it should be stressed that, on the whole, Oyono-Mbia is adequately proficient in both French and English. But since, as our analysis shows, his works contain fewer French than English mistakes, it follows that he has a better command of French than English, although he expresses himself with sufficient ease and competence in both languages to be justifiably considered to be a bilingual playwright. It is hardly surprising that he should have a greater mastery of French than English for, not only did he learn French as his first foreign language and received instruction up to the first degree in it, he has also spent most of his life in his home town and Yaounde which are situated in the French-speaking part of Cameroun.

\section{UNIONMWAN EDEBIRI}

University of Lagos, Lagos, Nigeria

\section{Notes}

I have used the following abbreviations in the quotations in this article:

- Trois prétendants - Trois prétendants un mari

- Three Suitors - Three Suitors - One Husband

- Jusqu'à-Jusqu'à nouvel avis

- Until - Until Further Notice

- Le train - Le train spécial de Son Excellence

- His Excellency's - His Excellency's Special Train

1. Maurice van Overberke: Introduction au problème du bilinguisme, Bruxelles, Labor et Paris, Feru and Nathan, p. 119. 
2. Rene Haeseryn (1977): "The Role of Specialized Non-Literary Translation in the Development of General and Specialized Language," Babel, 3, vol. XXIII, p. 103.

3. The importance of translating drama texts with performance in view and the recognition of the changing nature of acting styles and concepts of drama have led some critics to suggest that the translation of a play should be undertaken every fifty years. $C f$. Georges Mounin (1968): "Traduction au théâtre," Babel, vol. XIV, no. 1, pp. 7-11.

4. "The Translation of Literature: An Approach", Babel, vol. XVI, no. 2, 1970, p. 79.

5. Cameroon was a German colony until the First World War. After the war, the eastern part was administered by the French while the western part was administered by the British under the trusteeship of the League of Nations. Both parts were reunited to form the Federal Republic of Cameroon on 1st October 1961

6. Ekundayo Simpson (1978): Samuel Beckett: traducteur de lui-même, Aspects de bilinguisme littéraire, Publication B-79, Quebec: CIRB / ICRB. I found this work particularly helpful in writing the present article.

\section{REFERENCES}

OYONO-MBIA, G. (1964): Trois prétendants... un mari, Yaoundé, Éditions CLE.

OYONO-MBIA, G. (1968): Three Suitors... One Husband/Until Further Notice, London, Methuen and Co. Ltd.

OYONO-MBIA, G. (1970): Jusqu'à nouvel avis, Yaoundé, Éditions CLE.

OYONO-MBIA, G. (1979) Le train spécial de Son Excellence/His Excellency's Special Train, Yaoundé, Éditions CLE. 